\title{
Ebola preparedness in the Western Pacific Region, 2014
}

\author{
Xu Zhen, ${ }^{a^{*}}$ Boris Pavlin, ${ }^{b^{*}}$ Raynal C. Squires, ${ }^{a}$ Thilaka Chinnayah, ${ }^{a}$ Frank Konings, ${ }^{a}$ Chin-Kei Lee ${ }^{a}$ and Li Ailan ${ }^{a}$ on \\ behalf of the World Health Organization Regional Office for the Western Pacific Ebola Emergency Support Team \\ Correspondence to Xu Zhen (email: xuz@wpro.who.int).
}

West Africa is currently experiencing the largest outbreak of Ebola virus disease (EVD) in history with intense transmission in several affected countries. For non-affected countries, the best protective measures are adequate levels of preparedness including vigilant surveillance to detect cases early and well-prepared health systems to ensure rapid containment of the virus and to avoid further spread. The World Health Organization Regional Office for the Western Pacific recently conducted two activities: a web-based EVD preparedness survey and an EVD simulation exercise to determine the overall level of EVD preparedness in the Region. The survey and exercise together demonstrate there is a good overall level of preparedness for a potential imported case of EVD in the Western Pacific Region. However, a number of areas still require further strengthening before the Region can efficiently and effectively respond to potential EVD events, including laboratory testing arrangements; clinical management and infection prevention and control; and public health intervention measures, particularly at points of entry. Importantly, the survey and exercise also highlight the unique situation in Pacific island countries and emphasize that special considerations are needed to better support these countries in EVD preparedness.

$\mathrm{T}$ he largest outbreak of Ebola virus disease (EVD) in history has been ongoing in West Africa since December 2013. ${ }^{1}$ Recent transmission of EVD outside of West Africa in the United States of America and Spain ${ }^{2,3}$ suggests that no region of the world is immune to either the introduction or the onward transmission of EVD.

There are no direct flights between the three countries with widespread transmission of EVD in West Africa and any countries in the Western Pacific Region; on the other hand, a number of countries in the Region have economic or other ties with Africa. Risk assessments conducted by the World Health Organization (WHO) Regional Office for the Western Pacific ${ }^{4}$ suggest that the possibility of imported EVD cases to the Region is not high, but if it occurs the consequences would be major. The consequences of an introduction, particularly in developing country settings such as those found in many Pacific island countries, would likely be severe. Many of these countries are characterized by poor health-care infrastructure, low health-seeking behaviour, crowded housing, close-knit yet extensive social networks, low levels of sanitation and hygiene, low health literacy and challenging infrastructure. In light of this, a framework for action to respond to Ebola virus

disease for the Western Pacific Region was developed by the WHO Regional Office for the Western Pacific to assist unaffected countries and areas in the Region set priorities for preparedness to detect and respond to an outbreak of EVD. The framework for action provides a useful checklist for countries in the Region to determine their preparedness in key areas related to EVD. ${ }^{5}$

As part of its support to Member States, and within the context of the International Health Regulations (IHR 2005) ${ }^{6}$ and the Asia Pacific Strategy for Emerging Diseases (APSED 2010, a strategy for capacity-building for public health events in the South-East Asia and Western Pacific regions), ${ }^{7}$ the WHO Regional Office for the Western Pacific recently conducted two activities to assess EVD preparedness in the Region. The first of these was an online survey administered to the National IHR Focal Point in each Member State. The second was a simulation exercise conducted with the participation of the National IHR Focal Points in Member States, WHO country offices and the WHO Regional Office. The findings of these two activities can help National IHR Focal Points and the WHO Regional Office identify strengths and challenges regarding the preparedness level in the Region and help partners identify areas of potential support.

\footnotetext{
Emerging Disease Surveillance and Response Unit, Division of Health Security and Emergencies, World Health Organization Regional Office

for the Western Pacific, Manila, Philippines.

Office of the WHO Representative in Papua New Guinea, Port Moresby, Papua New Guinea.

* Both authors contributed equally in the writing of this paper.

Submitted: 12 December 2014; Published: 26 January 2015

doi: 10.5365/wpsar.2014.5.4.004
} 


\section{METHODS}

\section{Ebola preparedness survey}

Invitations to the web-based Ebola preparedness survey were sent to all 27 National IHR Focal Points in the WHO Western Pacific Region on 29 September 2014. The survey was not administered to non-self-governing areas within the Region, such as several Pacific island jurisdictions, as these do not have National IHR Focal Points. The survey consisted of self-reporting against 34 closed-ended ("yes" or "no") questions. Questions were related to the six components of the framework for action: (1) command and coordination; (2) surveillance, risk assessment and response; (3) laboratory; (4) clinical management, and infection prevention and control; (5) public health interventions, including points of entry measures; and (6) risk communication. Analysis was conducted for all countries and separately for Asian countries and Pacific island countries.

\section{Ebola simulation exercise}

An Ebola simulation exercise, which required National IHR Focal Points to respond quickly to incoming information by email regarding a potential EVD event, was conducted from 8 to 9 October 2014. Invitations to participate were sent to all 27 National IHR Focal Points in the Western Pacific Region.

Briefly, the exercise simulated the entry and detection of a travel-related EVD case in a local district in the National IHR Focal Points' country which required them to take rapid response actions. The exercise scenario and injects were designed to promote the following expected actions: (1) share national EVDrelevant guidelines and response plans; (2) provide technical advice on contact tracing, case management and patient transferral; (3) arrange specimen referral to WHO-recognized laboratories; (4) notify WHO of suspected and confirmed EVD cases under IHR (2005); and (5) draft the press release of the first announcement of an EVD case.

\section{RESULTS}

\section{Ebola preparedness survey}

Results of the survey are shown in Table 1 . Twenty-six National IHR Focal Points (96\%) completed the survey: Australia, Brunei Darussalam, Cambodia, China, Cook Islands, Fiji, Japan, Kiribati, the Lao People's Democratic Republic, Malaysia, the Marshall Islands, the Federated States of Micronesia, Mongolia, New Zealand, Niue, Palau, Papua New Guinea, the Philippines, the Republic of Korea, Samoa, Singapore, Solomon Islands, Tonga, Tuvalu, Vanuatu and Viet Nam.

The components of EVD preparedness with the highest number of positive responses for all countries on average were risk communication (86\%) and command and coordination (84\%). The lowest-scoring component was laboratory (60\%). Asian countries and Pacific island countries differed in their overall responses, with the Pacific island countries registering lower than their Asian counterparts in every component.

Within the command and coordination component, most Asian and Pacific island countries had plans and structures in place in case of an EVD event; $92 \%$ of Asian countries had tested or planned to test those plans, but only $8 \%$ of Pacific island countries had done so (prior to the simulation exercise described below).

In the surveillance, risk assessment and response component, an EVD surveillance protocol had been developed and disseminated to public health officials and hospitals in $92 \%$ of Asian countries compared to $15 \%$ of Pacific island countries. An investigation protocol had been developed in $100 \%$ of Asian countries compared to $31 \%$ of Pacific island countries. National rapid response teams (RRTs) had been briefed or trained on EVD response in $92 \%$ of Asian countries and countryspecific risk assessments conducted in $85 \% ; 31 \%$ of Pacific island countries reported completing either of the same preparedness actions.

In regard to laboratory preparedness, in-country capacity to diagnose suspected EVD cases was limited to Asian countries alone (10/13). However, 77\% of Asian countries and $54 \%$ of Pacific island countries reported having a referral arrangement in place, and $77 \%$ of countries in each subregion reported having staff trained to package specimens for referral.

For clinical management and infection, prevention and control, most countries in both subregions had a designated isolation facility, had an infection prevention and control guidelines in place and had given staff appropriate training. However, compared to $77 \%$ of 


\section{Table 1. Responses to a web-based survey of Ebola preparedness by Asian, Pacific island and all countries and areas, * WHO Western Pacific Region, 2014}

\begin{tabular}{|c|c|c|c|c|c|c|}
\hline Questions & $\begin{array}{l}\text { All countries } \\
\text { number/total }\end{array}$ & $\%$ & $\begin{array}{l}\text { Asian countries } \\
\text { number/total }\end{array}$ & $\%$ & $\begin{array}{l}\text { Pacific countries } \\
\text { number/total }\end{array}$ & $\%$ \\
\hline \multicolumn{7}{|l|}{ Command and coordination } \\
\hline $\begin{array}{l}\text { Is there a national public health emergency response } \\
\text { plan (or equivalent) that can be used to contain } \\
\text { potential EVD events? }\end{array}$ & $25 / 26$ & 96 & $13 / 13$ & 100 & $12 / 13$ & 92 \\
\hline $\begin{array}{l}\text { Is there an incident command and coordination } \\
\text { structure set up to coordinate the containment of } \\
\text { potential EVD events? }\end{array}$ & $25 / 26$ & 96 & $13 / 13$ & 100 & $12 / 13$ & 92 \\
\hline $\begin{array}{l}\text { If an EVD case were to occur, would EOC in } \mathrm{MOH} \text { be } \\
\text { activated for response operations? }^{\dagger}\end{array}$ & $23 / 25$ & 92 & $11 / 12$ & 92 & $12 / 13$ & 92 \\
\hline $\begin{array}{l}\text { Has an EVD exercise/simulation been planned or } \\
\text { conducted? }\end{array}$ & $13 / 26$ & 50 & $12 / 13$ & 92 & $1 / 13$ & 8 \\
\hline Average & & 84 & & 96 & & 71 \\
\hline \multicolumn{7}{|l|}{ Surveillance, risk assessment and response } \\
\hline $\begin{array}{l}\text { Is } \mathrm{MOH} \text { monitoring the EVD situation in } \\
\text { West Africa? }\end{array}$ & $26 / 26$ & 100 & $13 / 13$ & 100 & $13 / 13$ & 100 \\
\hline $\begin{array}{l}\text { Has awareness of EVD been raised among health- } \\
\text { care workers? }\end{array}$ & $24 / 26$ & 92 & $12 / 13$ & 92 & $12 / 13$ & 92 \\
\hline $\begin{array}{l}\text { Has a country-specific risk assessment been } \\
\text { conducted? }\end{array}$ & $15 / 26$ & 58 & $11 / 13$ & 85 & $4 / 13$ & 31 \\
\hline $\begin{array}{l}\text { Are the existing event-based surveillance/indicator- } \\
\text { based surveillance systems used to detect potential } \\
\text { EVD cases? }\end{array}$ & $22 / 26$ & 85 & $13 / 13$ & 100 & $9 / 13$ & 69 \\
\hline $\begin{array}{l}\text { Has a case/event definition of EVD been developed in } \\
\text { your country? }\end{array}$ & $20 / 26$ & 77 & $13 / 13$ & 100 & $7 / 13$ & 54 \\
\hline $\begin{array}{l}\text { Has an EVD surveillance protocol been developed and } \\
\text { disseminated to public health officials and hospitals? }\end{array}$ & $14 / 26$ & 54 & $12 / 13$ & 92 & $2 / 13$ & 15 \\
\hline $\begin{array}{l}\text { Is there a reporting mechanism in hospitals to report } \\
\text { unusual events/cases to public health authorities? }\end{array}$ & $25 / 26$ & 96 & $13 / 13$ & 100 & $12 / 13$ & 92 \\
\hline $\begin{array}{l}\text { Has an investigation protocol/flow chart for EVD cases } \\
\text { been developed? }\end{array}$ & $17 / 26$ & 65 & $13 / 13$ & 100 & $4 / 13$ & 31 \\
\hline Are contact tracing/management guidelines available? & $22 / 26$ & 85 & $12 / 13$ & 92 & $10 / 13$ & 77 \\
\hline $\begin{array}{l}\text { Has the national RRT been briefed/trained on EVD } \\
\text { response? }^{\dagger}\end{array}$ & $15 / 25$ & 60 & $11 / 12$ & 92 & $4 / 13$ & 31 \\
\hline $\begin{array}{l}\text { Is there a mechanism to notify WHO of a suspected } \\
\text { case through the International Health Regulations } \\
\text { (IHR 2005)? }\end{array}$ & $26 / 26$ & 100 & $13 / 13$ & 100 & $13 / 13$ & 100 \\
\hline Average & & 79 & & 96 & & 63 \\
\hline \multicolumn{7}{|l|}{ Laboratory } \\
\hline $\begin{array}{l}\text { Is there in-country laboratory capacity for testing } \\
\text { suspected EVD specimens? }\end{array}$ & $10 / 26$ & 38 & $10 / 13$ & 77 & $0 / 13$ & 0 \\
\hline $\begin{array}{l}\text { Has a referral arrangement with a WHO-recognized } \\
\text { laboratory for Ebola virus diagnosis been made? }\end{array}$ & $17 / 26$ & 65 & $10 / 13$ & 77 & $7 / 13$ & 54 \\
\hline $\begin{array}{l}\text { Are there staff trained to organize air shipment of } \\
\text { specimens (Ebola virus or any other agent) according } \\
\text { to IATA guidelines? }\end{array}$ & $20 / 26$ & 77 & $10 / 13$ & 77 & $10 / 13$ & 77 \\
\hline Average & & 60 & & 77 & & 44 \\
\hline
\end{tabular}

* Asian countries included Australia, Brunei Darussalam, Cambodia, China, Japan, the Lao People's Democratic Republic, Malaysia, Mongolia, New Zealand, Papua New Guinea, the Philippines, the Republic of Korea, Singapore and Viet Nam; Pacific island countries included Cook Islands, Fiji, Kiribati, the Marshall Islands, the Federated States of Micronesia, Niue, Palau, Samoa, Solomon Islands, Tonga, Tuvalu and Vanuatu.

$\dagger$ Based on available survey results.

EOC, Emergency Operations Centre; EVD, Ebola virus disease; IATA, International Air Transport Association; MOH, Ministry of Health; POE, points of entry; RRT, rapid response team. 
Table 1. Responses to a web-based survey of Ebola preparedness by Asian, Pacific island and all countries and areas,* WHO Western Pacific Region, 2014 (continued)

\begin{tabular}{|c|c|c|c|c|c|c|}
\hline Questions & $\begin{array}{l}\text { All countries } \\
\text { number/total }\end{array}$ & $\%$ & $\begin{array}{l}\text { Asian countries } \\
\text { number/total }\end{array}$ & $\%$ & $\begin{array}{l}\text { Pacific countries } \\
\text { number/total }\end{array}$ & $\%$ \\
\hline \multicolumn{7}{|l|}{ Clinical management \& infection prevention and control } \\
\hline $\begin{array}{l}\text { Has your country designated a hospital/hospitals for } \\
\text { EVD cases? }\end{array}$ & $22 / 26$ & 85 & $13 / 13$ & 100 & $9 / 13$ & 69 \\
\hline $\begin{array}{l}\text { Have infection prevention and control guidelines that } \\
\text { can be used for EVD response been developed and } \\
\text { disseminated? }\end{array}$ & $19 / 26$ & 73 & $10 / 13$ & 77 & $9 / 13$ & 69 \\
\hline $\begin{array}{l}\text { Is there an adequate supply of personal protective } \\
\text { equipment in your country for EVD rapid response and } \\
\text { containment operations? }\end{array}$ & $12 / 26$ & 46 & $10 / 13$ & 77 & $2 / 13$ & 15 \\
\hline $\begin{array}{l}\text { Has training on personal protective equipment for } \\
\text { health-care workers been given in the designated } \\
\text { hospital/hospitals? }\end{array}$ & $20 / 26$ & 77 & $13 / 13$ & 100 & $7 / 13$ & 54 \\
\hline Average & & 70 & & 89 & & 52 \\
\hline \multicolumn{7}{|l|}{ Public health interventions including POE measures } \\
\hline $\begin{array}{l}\text { Have public health measures been identified to } \\
\text { contain potential EVD events? }{ }^{+}\end{array}$ & $19 / 25$ & 76 & $12 / 12$ & 100 & $7 / 13$ & 54 \\
\hline $\begin{array}{l}\text { Is there a public health emergency contingency plan } \\
\text { in place at POE that can be used for EVD event } \\
\text { management? }\end{array}$ & $20 / 26$ & 77 & $11 / 13$ & 85 & $9 / 13$ & 69 \\
\hline $\begin{array}{l}\text { Have POE staff been sensitized/briefed on appropriate } \\
\text { action to manage suspected EVD cases in arriving } \\
\text { travellers? }\end{array}$ & $17 / 26$ & 65 & $13 / 13$ & 100 & $4 / 13$ & 31 \\
\hline $\begin{array}{l}\text { Is there a separate area for rapid assessment and } \\
\text { isolation of suspected EVD cases at POE? }\end{array}$ & $20 / 26$ & 77 & $12 / 13$ & 92 & $8 / 13$ & 62 \\
\hline $\begin{array}{l}\text { Is there a mechanism at POE for referral of ill } \\
\text { travellers to designated hospitals? }\end{array}$ & $23 / 26$ & 88 & $13 / 13$ & 100 & $10 / 13$ & 77 \\
\hline $\begin{array}{l}\text { Is there a protocol to monitor and manage returning } \\
\text { travellers with Ebola-like symptoms? }\end{array}$ & $16 / 26$ & 62 & $13 / 13$ & 100 & $3 / 13$ & 23 \\
\hline $\begin{array}{l}\text { Is EVD-related information for both incoming and } \\
\text { outgoing travellers available at POE? }\end{array}$ & $15 / 26$ & 58 & $11 / 13$ & 85 & $4 / 13$ & 31 \\
\hline Average & & 72 & & 95 & & 50 \\
\hline \multicolumn{7}{|l|}{ Risk communication } \\
\hline $\begin{array}{l}\text { Has the relevant EVD information been disseminated } \\
\text { to the general public? }\end{array}$ & $20 / 26$ & 77 & $11 / 13$ & 85 & $9 / 13$ & 69 \\
\hline $\begin{array}{l}\text { Is there a risk communication plan in place to } \\
\text { communicate with stakeholders and the public during } \\
\text { an EVD event? }\end{array}$ & $21 / 26$ & 81 & $13 / 13$ & 100 & $8 / 13$ & 62 \\
\hline $\begin{array}{l}\text { Is there a procedure/mechanism in place to rapidly } \\
\text { disseminate EVD information and health messages? }\end{array}$ & $24 / 26$ & 92 & $13 / 13$ & 100 & $11 / 13$ & 85 \\
\hline $\begin{array}{l}\text { Is there a designated spokesperson in } \mathrm{MOH} \text { for } \\
\text { emerging diseases/outbreaks? }\end{array}$ & $24 / 26$ & 92 & $13 / 13$ & 100 & $11 / 13$ & 85 \\
\hline $\begin{array}{l}\text { Is there a mechanism in place for first announcement } \\
\text { (if an EVD case were to occur)? }\end{array}$ & $23 / 26$ & 88 & $12 / 13$ & 92 & $11 / 13$ & 85 \\
\hline Average & & 86 & & 95 & & 77 \\
\hline
\end{tabular}

* Asian countries included Australia, Brunei Darussalam, Cambodia, China, Japan, the Lao People's Democratic Republic, Malaysia, Mongolia, New Zealand, Papua New Guinea, the Philippines, the Republic of Korea, Singapore and Viet Nam; Pacific island countries included Cook Islands, Fiji, Kiribati, the Marshall Islands, the Federated States of Micronesia, Niue, Palau, Samoa, Solomon Islands, Tonga, Tuvalu and Vanuatu.

$\dagger$ Based on available survey results.

EOC, Emergency Operations Centre; EVD, Ebola virus disease; IATA, International Air Transport Association; MOH, Ministry of Health; POE, points of entry; RRT, rapid response team. 
Asian countries only $15 \%$ of Pacific island countries had adequate personal protective equipment to actually manage a potential EVD case.

There was great discrepancy between Asian countries and Pacific island countries with regard to public health intervention measures at points of entry. All Asian countries had briefed points of entry staff on the management of suspected EVD in arriving passengers, all had a protocol in place to monitor and manage returning travellers with EVD-like symptoms and $85 \%$ had EVD-related information available for both incoming and outgoing travellers at points of entry. In the same respective categories, $31 \%, 23 \%$ and $31 \%$ of Pacific island countries reported having completed those preparations.

Risk communication capacity was high in both groups, with few components requiring further strengthening; Pacific island countries demonstrated a median level of EVD public awareness dissemination $(69 \%)$ and development of risk communication plans for the event of an EVD outbreak (62\%).

\section{Ebola simulation exercise}

Twenty-three National IHR Focal Points participated in the exercise; 11 from Asian countries on 8 October and 12 from Pacific island countries on 9 October. Countries participating in the exercise were: Brunei Darussalam, Cambodia, China, Cook Islands, Fiji, Japan, Kiribati, the Lao People's Democratic Republic, Malaysia, the Marshall Islands, the Federated States of Micronesia, Mongolia, Niue, New Zealand, Palau, the Philippines, the Republic of Korea, Samoa, Singapore, Solomon Islands, Tuvalu, Vanuatu and Viet Nam. Five of the National IHR Focal Points (Fiji, Kiribati, the Federated States of Micronesia, the Republic of Korea and Vanuatu) participated but could not complete the exercise due to communication, technical or personnel constraints. The National IHR Focal Points of Australia, Nauru, Papua New Guinea and Tonga did not participate.

The exercise demonstrated that Asian countries are well advanced in the preparation of national EVD response plans or relevant guidelines. During the exercise, all 11 Asian countries were able to share the existing national EVD guidelines/response plans that had been developed in-country. Some Asian countries had developed very comprehensive response plans which included key components of emergency response coordination and communication. In contrast, only $30 \%$ of Pacific island countries could share EVD-relevant guidelines developed prior to the exercise.

All Asian country National IHR Focal Points were able to provide technical guidance to the simulated local public health unit on patient referral, contact tracing and case management. Some countries provided very technical and detailed advice and necessary assistance that could be beneficial at the local level. All Pacific island countries were able to provide advice on patient referral, contact tracing and management as well, but there were some technical inaccuracies with the materials provided by some Pacific island countries.

During the exercise, all Asian country and Pacific island country National IHR Focal Points were able to facilitate laboratory testing of simulated EVD specimens, although there was some minor confusion about referral mechanisms. National IHR Focal Points from two Asian countries with EVD diagnostic capacity declared that specimens only required in-country testing, while others understood the need for referral but were not clear about where specimens should be shipped. WHO requests that, at least initially, clinical specimens diagnosed in-country be shipped to specific WHO-recognized laboratories for confirmation.

Under IHR (2005), suspected or confirmed cases of EVD should be notified to WHO. Fifteen countries notified WHO of the individual meeting a suspected case definition in the scenario (9/11 Asian countries; 6/10 Pacific island countries), and 17 notified WHO of the confirmed case (9/11 Asian countries; 8/10 Pacific island countries). In total, $91 \%$ (10/11) of the Asian countries and $80 \%(8 / 10)$ of Pacific island countries notified WHO of either suspected or confirmed EVD cases.

Sixteen of the participating National IHR Focal Points (from 10/11 Asian countries and 6/10 Pacific island countries) were able to share a draft first announcement upon simulated confirmation of the EVD case, but difficulties were noted in some countries' ability to develop a well-written press release, especially in Pacific island countries. 


\section{DISCUSSION}

The survey and simulation exercise suggest that there is a good overall preparedness level in the Western Pacific Region in the event of an imported case of EVD. However, a number of areas still require further strengthening before the Region can efficiently and effectively respond to potential EVD events, including laboratory testing arrangements; clinical management and infection prevention and control; and public health intervention measures, particularly at points of entry. Importantly, the survey and exercise demonstrated that several countries were not completely ready to facilitate specimen testing. It was not expected that all countries (especially Pacific island countries) would have the appropriate facilities and biosafety infrastructure for in-country testing of suspected EVD specimens, but an adequate referral mechanism to facilitate specimen testing should be in place. Countries need to ensure fully that agreements have been made with WHO-recognized laboratories for confirmatory testing, have sufficiently trained staff to safely and correctly package suspected specimens and that export arrangements for dangerous goods have been prepared so that shipments will be smooth and efficient.

Both the survey and the simulation exercise highlight the unique situation and requirements of Pacific island countries compared to Asian countries and emphasize that special considerations for Pacific island countries are needed in terms of EVD preparedness, in particular specimen testing, interventions at points of entry and availability of personal protective equipment. The implications of the survey and exercise should extend beyond stakeholders in health, as the experience in West Africa has shown that an extensive EVD outbreak impacts and necessitates a response from the whole of society.

As the survey was based on country self-reporting, it is difficult to objectively assess whether the results provided are a true reflection of country capacity. To some extent, this was addressed by having the simulation exercise, which sought to elicit objective evidence of certain preparedness capacities such as the ability to quickly produce guidance documents. Still, many capacities were unable to be tested due to the tabletop nature of the simulation. This further underscores the need for in-country functional or full-scale exercises to truly assess capacity.
A limitation of the simulation exercise was that the personnel available to participate varied from one country to another. For example, one country had 20 participants, while another had only one to two participants as it was a national holiday. Thus, the performance in the exercise may not have been a true reflection of that country's actual capacity.

The survey and simulation exercise did not include the non-sovereign areas of the Pacific (e.g. American Samoa, Guam and French Polynesia); therefore, the preparedness levels in these areas could not be assessed. While many of the issues faced by these areas are likely similar to those encountered in their developing country neighbours, it is expected that they would have access to resources from their metropolitan governments (in this case, the United States and France, respectively). Other countries in the Region with close political ties to developed countries (e.g. Papua New Guinea to Australia, and the northern Micronesian countries to the United States) would probably benefit from similar support if an outbreak were to occur in their jurisdictions. It is in the interest of regional security for all that high-resource countries increase their support to developing countries; should an outbreak of EVD occur in an inadequately prepared developing country, patients seeking better care would likely flee to their high-resource, traditional allies. It would be far more cost-effective and politically acceptable for all countries involved to prevent such outbreaks in the first place.

The EVD outbreak in West Africa has served as a high alert to all countries against becoming complacent about the threat of emerging diseases and as an opportunity to test the public health and social systems that countries have put in place to deal with such threats. Many of the assessed elements of preparedness referenced here were generic capacities that could be used for a variety of events, not solely an EVD outbreak. Generic capacities allow for the quick adaptation of surveillance and response systems to novel or (re-)emerging pathogens, such as Ebola virus; this is particularly critical in developing country settings, such as the Pacific island countries, in which it is simply not feasible to have vertical approaches to each novel disease. APSED provides a foundation for generic public health emergency system strengthening based on its focus areas and contributions towards achieving IHR (2005) core capacities, but more remains to be 
done. Donors and technical partners can use the results of the preparedness survey and simulation exercise to prioritize urgent support to Member States to further advance these capacities, particularly in the areas of laboratory, case management, infection prevention and control and points of entry, particularly in the Pacific subregion. Further EVD-specific preparedness can be achieved through application of the framework for action. $^{5}$

\section{Conflicts of interest}

None declared.

\section{Funding}

None.

\section{Acknowledgements}

The WHO Regional Office for the Western Pacific Ebola Emergency Support Team acknowledges all Member States in the Western Pacific for their contribution and support to the Ebola preparedness survey and Ebola simulation exercise.

Other members of the WHO Western Pacific Region Ebola Emergency Support Team when the survey and exercise were conducted: Kotaro Tanaka,
Selenic Dubravka, May Chiew, Christine Cool, Samantha Chapman, Christophe Delaude and Janet Mina.

\section{References:}

1. Ebola Virus Disease Fact Sheet No 103, September 2014. Geneva, World Health Organization, 2014 (http://who.int/mediacentre/ factsheets/fs103/en/, accessed 10 November 2014).

2. Ebola Response Roadmap Situation Report. 8 October 2014. Geneva, World Health Organization, 2014 (http://apps.who.int/ iris/bitstream/10665/136020/1/roadmapsitrep_80ct2014_eng. pdf?ua =1, accessed 13 November 2014).

3. Cases of Ebola diagnosed in the United States. Atlanta, Centers for Disease Control and Prevention (CDC), 2014 (http://www.cdc. gov/vhf/ebola/outbreaks/2014-west-africa/united-states-importedcase.html, accessed 13 November 2014).

4. Ebola virus disease: Risk assessment in the Western Pacific Region - 09 October 2014. Manila, World Health Organization Regional Office for the Western Pacific, 2014 (http://www.wpro. who.int/outbreaks_emergencies/wpr_ra_ebola_09oct2014. pdf?ua $=1$, accessed 13 November 2014).

5. Preparedness for a potential outbreak of Ebola virus disease: a framework for action in the Western Pacific Region. Manila, World Health Organization Regional Office for the Western Pacific, 2014 (http://www.wpro.who.int/outbreaks_emergencies/wpro ebola/en/, accessed 13 November 2014).

6. International Health Regulations. (2005), Second edition. Geneva, World Health Organization, 2008 (http://www.who.int/ ihr/9789241596664/en/, accessed 13 November 2014).

7. Asia Pacific Strategy for Emerging Diseases (APSED, 2010). Manila, World Health Organization Regional Office for the Western Pacific, 2011 (http://www.wpro.who.int/emerging_diseases/ APSED2010/en/, accessed 13 November 2014). 